\title{
Gender Sensitivity in Early Childhood Education in Malang City
}

\author{
Trisakti Handayani \\ University of Muhammadiyah Malang \\ trisaktihandayaniwidodo@gmail.com
}

\begin{abstract}
This current study aimed at: 1) Explaining the teachers' understanding on the gender concept in Early Childhood Education; 2) exploring the instructional strategies for Early Childhood Education; and 3) analyzing gender sensitivity in Early Childhood Education. This study employed a qualitative research approach by means of descriptive analysis. There were two data required to support this study, primary and secondary data. Early Childhood Educations in Malang City were selected as the subjects of this study. To collect the data, observation, interview, and documentation were conducted. Meanwhile, for data analysis, a descriptive-qualitative approach was chosen to execute, assisted by Harvard technique of analysis. This study has revealed that: 1) the teachers still lack understanding on the gender concept in the Early Childhood Education; 2) piloting any dissemination and training in respect to gender for the stakeholders and teachers has been considered to be the best instructional strategy to be implemented in the Early Childhood Education; and 3) gender sensitivity in the Early Childhood Education has been shown to be relatively low that the instructional activities have not characterized any genderequality atmosphere.
\end{abstract}

Key words: sensitivity, gender, and early childhood education

\section{INTRODUCTION}

The most fundamental mission of education is to get students prepared so as to enlighten their perspectives for a better life, guide them to a very meaningful way of life, and uplift their welfare far better than that of before [1].

Indonesia has approved to sign the Sustainable Declaration on the United Nations High-Level Meeting in which one of the agreed pacts refers to its concern on the humans' rights, especially to provide the primary education for everyone and to promote gender equality and woman empowerment [2].

Another international commitment that has been the referral pact of SDG's is MDG's, Declaration of Dakar, about Education for All Policy, in which Indonesia has taken aside to be one of the UNESCO members to ratify[3]. Gender mainstreaming represents the national and international pledges for the sake of gender equality and justice [4]. By then, all citizens are facilitated to make a maximum enhancement for their potentials [5]

"Children have already learned a great deal about gender roles before they enter school."'[6]. Some experts have suggested that it refers to their golden ages, where their brilliance in this stage is supposed to grow faster up to $50 \%$. "Gender is another key dimension of children's development."[7]. Introducing gender role to them in their golden ages has significant effect to their behavior and characteristic development as well as establishment in the future.

To this end, gender construction within the patriarchic culture, to place males and females differently, would not be suitable to be adopted as it cannot meet democratic values [8]. Gender bias happening in the Early Childhood Education in East Java has been identifiable from a number of educational aspects with a parity index, in which the performance distribution between males and females shows a tendency to malign the former with the following specifications: to the students of the Early Childhood Education (signifying 1.31), to the administrators of the playgroup (denoting 5.03), to the teachers of the playgroup (constituting 23.45), to the administrators of the Early Childhood Education (representing 7.36) and to the teachers of the Early Childhood Education (4.52). It is obvious from all indicators that women have more significant involvement in the educational setting than those of men, thus gender bias is said to occur [9].

The most crucial issues gender mainstreaming should deal with are the matters of access to and even distribution of the primary education. It is manifested by the priority absence for the distribution of the gender policies in the primary education despite any efforts for dissemination programs by means of capacity building, publication, or other formats [10]. This is also supported by the study conducted by [1], who posit that the implementation of gender-based education in the Early Childhood Care and Development-Resource Center (ECCD-RC) was piloted by habituation, exemplification, and non-discriminatory games. Another relevant study was conducted by [11], who denote thatthe plan to introduce the gender roles within the instructional activities is to be set in the form of daily activities referring to the Decree of The Ministry of Education Number 58 Year 2009.

Alluding to the aforesaid exploration, it is of urgency to establish an analysis on the gender sensitivity in the Early Childhood Education. The analysis, furthermore, would pinpoint two cores of gender issues in the instruction: the first denoting the educational access and distribution as well as the instructional accountability and management; and the second referring to any issues regarding gender in the instructional activities that are supposed to be the instruments for analysis in order to portrait the real condition of the existence of gender bias in the level of Early Childhood Education in Malang City. 


\section{METHOD}

A qualitative approach was employed to conduct this study [12], by means of descriptive analysis. The current study was conducted in Anak Saleh, Al-Amin, and Kasih Ibu Early Childhood Educations in Malang City. The researcher was plotted as the main instrument with the support of other assistive instruments to name interview guide, observation sheet, field note, recorder, and camera. The primary data were collected from the interview with the principals, teachers, and parents by also referring to the observation results during the instructional activities in the Early Childhood Education. Meanwhile, the secondary data were set as the supporting data that were gained from the documents related to the instructional activities conducted in the Early Childhood Educations. To collect the data, the following techniques were deployed: 1) on-site observation during the instructional activities; 2) interview with the principals, teachers, parents, and Gender Working Unit in Education and Culture Office of Malang City; 3) documentation was executed by collecting the supporting documents with respect to the instructional activities, such as curriculum files, books, games to pilot, and supportive facilities in the Early Childhood Educations. The data analysis was conducted by means of descriptive-qualitative supported by Harvard analysis technique.

\section{RESULTS}

Meaningful instructional activities could be achieved only if the materials are potentially meaningful to the students [14]. Nobody is born without any hopes for a better life. A critical pedagogy holds a very essential role for a democratic life [15].

The similar condition does not only exist in Indonesia as it also occurs in some parts of Europe, in which females lag seriously behind males.

"More women inEurope participating in sport activities, a lotremains to be done in the sphere of genderequality. Many women are today still unable tofind the right environment in which to developtheir full potential. In some countries, womenlag seriously behind men in access to sport". [16].

It is said that most of females today are hard to find the right environment to fully develop their potentials.

There are so many issues that may appear during the childhood or adulthood, which are actually rooted from the gender bias grown up since the early-childhood.[17].

The teachers, in fact, had different interpretation on the concept of gender. It, then, implies that they have defined the essence of gender differently in spite of the similarity of where the core path ends up. Some of them confessed that they had never initiatively attended the training session about gender held by the school or other education institutions. This occurrence is said to happen due to the fact that the term gender in education, especially in the Early Childhood Education, has not been so popular that it is assumed not really essential to know. Yet, some steps to reach the good understanding on the gender concept has been into initiation stage.

In nature, the teachers have shown to pilot a fair and equal education in regards to gender during the classroom instruction despite their unfamiliarity with the concept of gender equality they might unconsciously perform, all this time. They have been trying to treat all students equally during the classroom instruction. Everything was in its proper portion, no gender racism. Referring to the four aspects of children development, the following Table 1 serves the details.

Table 1. Aspects of Children Development

\begin{tabular}{lll}
\hline No. & Aspects & \multicolumn{1}{c}{ Details } \\
\hline 1. & Cognitive & $\begin{array}{l}\text { The development related to their } \\
\text { sense of thinking and self- } \\
\text { development } \\
\text { The development to control body } \\
\text { movements through an active } \\
\text { coordination of central nervous } \\
\text { system and muscles; The children's } \\
\text { motoric capacity refers to hard and }\end{array}$ \\
3. $\quad$ Language & $\begin{array}{l}\text { The capability of listening, speaking, } \\
\text { reading, and writing } \\
\text { The capability of showing anger, fear, } \\
\text { curiosity, joy, love, and care }\end{array}$ \\
& Socio- &
\end{tabular}

In effort of establishing gender-equality atmosphere, the Early Childhood Educations explicitly declare the terms 'the male and female students' and 'to develop any potentials the male and female students have innately possessed'.

The Early Childhood Educations have proposed the concept of educative playing with the program of excellence. The instructional activities held in the early Childhood Education were also enhanced by means of learning-while-playing method in Beyond Centre and Circle Time. The students were divided into small groups based on their ages and equal portion of distribution between male and female students.

Each of the groups was assisted by a classroom teacher with the ratio of 8-10 students. Every center was completed with educative playing tools where they were free to choose anything to play. The male students were not only allowed to pick boy's toys such as robots, cars, and so forth, and the same treatment applied to the female students. They were to choose based on their preferences and interests.

Any stories which may trigger discrediting certain gender were eliminated because the students had to be so sensitive to their surroundings. It signposted that whatever they listened to, witnessed, or underwent today, everything recorded would be fossilized and last long on their minds. If the story was very close to the issue of gender bias, then they might perform such action on their adulthood. 
Table 2. Indicators of Internalization for Gender Values

\begin{tabular}{|c|c|c|}
\hline Aspects & Description & Indicators \\
\hline Participation & $\begin{array}{l}\text { Participation in any } \\
\text { activities and decision } \\
\text { making }\end{array}$ & $\begin{array}{l}\text { a. The male and female students perform the same task in the classroom activities. } \\
\text { b. The male and female students are able to express their opinion during the instructional } \\
\text { activities. } \\
\text { c. The male and female students are to play together without any exception on the matter of } \\
\text { gender. } \\
\text { d. The male and female students are to get involved in all games. }\end{array}$ \\
\hline Access & $\begin{array}{l}\text { The probability to receive } \\
\text { and make use of sources }\end{array}$ & $\begin{array}{l}\text { a. The male and female students are able to make use of facilities for games without any } \\
\text { exception on the matter of gender. } \\
\text { b. The male and female students are able to take a lead over their friends, such as to pray, } \\
\text { and perform the daily responsibility. } \\
\text { c. The male and female students are able to solve the problems altogether. }\end{array}$ \\
\hline Control & $\begin{array}{l}\text { Rights or authorities to } \\
\text { make any decisions }\end{array}$ & $\begin{array}{l}\text { a. The male and female students are to get engaged in arranging the instructional materials. } \\
\text { b. The male and female students, altogether, determine any policies and agreements during } \\
\text { the instructional activities. } \\
\text { c. The male and female students are involved in instructional evaluation. }\end{array}$ \\
\hline Benefit & $\begin{array}{l}\text { Making use of source that } \\
\text { is optimally accessible }\end{array}$ & $\begin{array}{l}\text { The male and female students are allowed to join any instructional activities based on their } \\
\text { level of development. }\end{array}$ \\
\hline
\end{tabular}

As for the instructional activities, learning by doing model was implemented by way of fun games, but it is still the frame of the expected goals. In terms of character building, the exemplification (modeling) technique was chosen to be performed in school and home environment with a directory system that allowed the school parties and parents to maintain a strong engagement.

There have been a couple of instructional patterns shown in the Early Childhood Educations, such as: 1) attitudes upon themselves; 2) attitudes upon their friends; 3) attitudes upon the teachers; 4) attitudes upon the environment; and 5) praying before and after eating. The followings are the interaction patterns shown by the students during the instructional activities based on Harvard analysis.

Gender equality perspective needs to be inserted into relevant materials, as, in fact, not all of them are applicable to be integrated explicitly in any topic of discussion. Gender sensitivity during the instructional activities in the Early Childhood Educations is still in the minimum level so that it still represents the atmosphere of gender inequality.

\section{CONCLUSION}

The teachers still have lack understanding on the gender concept in the Early Childhood Education, which is shown by the way how they conducted their instructional activities;

The instructional strategies for the Early Childhood Education in effort of raising gender sensitivity could be performed by conducting disseminations and trainings about gender concept to the stakeholders and teachers, and by stipulating gender-sensitive policies to the Early Childhood Education; and

Gender sensitivity on any instructional activities in the Early Childhood Educations is still considered to be relatively low in level that it has not portrayed the nature of gender equality.

\section{REFERENCES}

[1] Roziqoh and Suparno. Gender Perspective Education to Early Chilhood. Jurnal Pendidikandan Pemberdayaan Masyarakat, Volume1-Number 1.March. 2014.

[2] UNDP. The Sustainable Development Goal's Report.New York. 2017.

[3] Unesco. Panduan Perencanaan Pendidikan Untuk Semua (PUS) Asia Timur\& Asia Tenggara. Jakarta. 2002.

[4] Nurhaeni, I. D. A. P. Reformasi Kebijakan Pendidikan Menuju Kesetaraandan Keadilan Gender. Surakarta: LPP UNS. 2009.

[5] Permendiknas No.84 TH 2008 Tentang Pengarusutamaan Gender Bidang Pendidikan.

[6] Meece, Judith L. Child and Adolescent Development for Educators. New York: McGrawHill. 2002.

[7] Santrock, John W. Child Development. New York: McGraw-Hill. 2009.

[8] Maloutas, Maro Pantelidou. The Gender of Democracy.Citizenship and Gendered Subjectivity. New York: Routledge. 2006.

[9] Thorne, B. Gender play: Girls and boys in school. Buckingham: Open Univerity Press. 1993.

[10] Handayani, T., Sugiarti. Konsepdan Teknik Penelitian Gender. Universitas Muhammadiyah Malang Press. Malang. 2002.

[11] Tandayu, D., Syukri, M., and Masluyah. Pengenalan Peran Gender dalam Pembelajaran padaAnak Usia 5-6 Tahun di TK. Pendidikan Guru Pendidikan Anak Usia Dini FKIP UNTAN. Pontianak. 2015.

[12] Sutton, J. Qualitative Research: Data Collection, Analysis, and Management. The Canadian Journal of Hospital Pharmacy. May-Jun; 68 (3):226-231. 2015.

[13] Sugiyono. Metode Penelitian dan Pengembangan: Research and Development untuk Bidang 
Pendidikan, Manajemen, Sosial, dan Teknik. Bandung: Alfabeta. 2015.

[14] Basleman, Anisah and Syamsu Mappa. Teori Belajar Orang Dewasa. Bandung: Remaja Rosdakarya. 2011.

[15] Tilaar, H.A.R., Jimmy Ph. Paat, and Lody Paat. Pedagogik Kritis Perkembangan, Substansi, dan Perkembangannya di Indonesia. Jakarta: Rineka Cipta. 2011.
[16] Vassiliou, Androulla. "EU Commissioner for Education, Culture, Multilingualism, Youth and Sport".Journal GenderEquality in Sport. Page 3. 2014.

[17] Ismi, Dwi and Rutiana Dwi Wahyuningsih. Integrasi Pendidikan Adil Gender dalam Proses Pembelajaran di Sekolah Dasar. Surakarta: UNS. Press. 2007. 